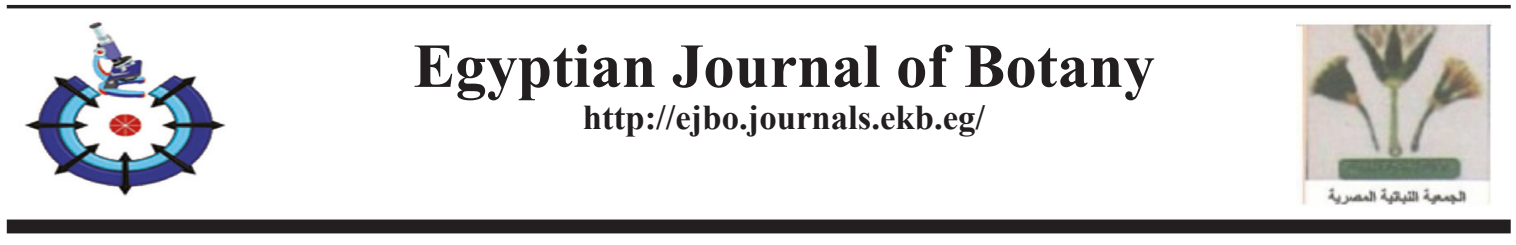

\title{
Anatomical Studies on the Genus Terminalia L. (Combretaceae) in Egypt, I- Leaf Structure
}

\author{
Nahed Waly ${ }^{(1)}$, Heba Moustafa ${ }^{(2)}$, Rim Hamdy ${ }^{(1)}$, Ashraf Soliman ${ }^{(1) \#}$ \\ ${ }^{(1)}$ Department of Botany and Microbiology, Faculty of Science, Cairo University, \\ Giza, Egypt; (2) National Organization for Drug and Control Research, Giza, Egypt.
}

\begin{abstract}
$\boldsymbol{T}$ ERMINALIA in Egypt is represented by nine species. The locations of the different collected species were georeferenced with a GPS device. The samples were identified at the Cairo University Herbarium (CAI). Anatomical sections were investigated with a light microscope; Olympus BX51. Photomicrographs were taken using photomicroscope; Olympus DP12. Twenty-four anatomical characters have significant diversity. In leaf, type of mesophyll, length of palisade tissue, number and size of the main and accessory vascular bundles, presence or absence of vascular bundles in small veins as well as lysigenous ducts and crystals. In petiole, the number, shape and distribution of the main and accessory vascular bundles, types of bundle sheath, number of lysigenous ducts, etc. Qualitative and quantitative data of the anatomical characters have been investigated through numerical method by using the unweighted pair group method with arithmetic mean (UPGMA). An artificial key was constructed that could be a taxonomic delimitation for comparison between species. This Study proposed that anatomical features of leaf lamina and petiole of Terminalia species investigated should be used as an effective delimitation for authentication and differentiation between the species.
\end{abstract}

Keywords: Anatomy; Combretaceae, Leaf, Petiole, Terminalia, UPGMA.

\section{Introduction}

Terminalia L. is a pantropical genus growing across the tropical areas of Africa, Asia, America and subtropical regions of Australia and Pacific Islands, considered to be the second- largest genus of the family Combretaceae comprising more than 200 species of trees and shrubs (Stace, 2002). The 54 species of Terminalia are distributed across eastern, western and southern Africa (Lebrun \& Stork, 1991; Smith et al., 2004). Taxonomic treatment of Terminalia has long been recognized by many workers (Clarke, 1878; Engler \& Diels, 1900; Exell, 1954, 1978; Griffiths, 1959; AlMayah, 1983; Pedley, 1990).

The species of this genus differ greatly in anatomy, morphology and karyotype features
(Stace, 1965; Ohri, 1996). According to Wickens (1973) and Fyhrquist (2007), the morphological characters of the bark, leaf and fruit are remarkably different throughout the genus and could be a significant guide for the identification of taxa. In case of incomplete materials, the anatomical features could be useful (Noraini \& Cutler, 2009).

Several studies including the anatomy of Combretaceae were discussed (Heiden, 1893a, b; Solereder, 1908; Verhoeven, 1969; Verhoeven \& Vander- Schüff, 1973, 1974). Moreover, Metcalfe \& Chalk (1950) described the anatomical features of the family with some specification on genus Terminalia and emphasized the importance of the arrangement of sclerenchymatic cells surrounding the vascular bundles.

\#Corresponding author email: ashsoliman@sci.cu.edu.eg

Mobile No.: 00201006072285

Received 24/11/2019; Accepted 2/5/2020

DOI : 10.21608/ejbo.2020.20019.1398

Edited by: Prof. Fco Martin Dr. Huerta-Martinez, University of Guadalajara, Mexico.

(C)2020 National Information and Documentation Center (NIDOC) 
As well, the study of leaf epidermis of Terminalia has been documented by Stace (1965), Nawani \& Kulshreshtha (1982) and Narasimha Rao \& Ramayya (1984).

The leaves in Terminalia are simple, alternate, subopposite or spirally rarely opposite arranged, single along the shoots or clustered at the end of branches with brochidodromous venation, exstipulate, margin slightly crenulate, glabrous or pubescent, often minutely verrucose with 2 or more glands at or near the base of the blade or at the top of the petiole.

Medical, cultural, religious and social importance has been recorded throughout the genus (Irvine, 1961; Srivastava et al., 1992; Lemmens et al., 1995; Schmidt et al., 2002; Smith et al., 2004; Satardekar \& Deodhar, 2010; Sharma \& Mukundan, 2014; Rathinamoorthy \& Thilagavathi, 2014). In Africa and Asia, traditional remedy from Terminalia species has been utilized (Lawes et al., 2004; Steenkamp et al., 2004; Moshi $\&$ Mbwambo, 2005). As well pharmaceuticals and cosmetics preparations utilized Terminalia species as sources of raw materials (Dalziel \& Hutchinson, 1937; Irvine, 1961). Derivatives of Terminalia species are used in the remedy of many diseases such as diabetics, eczema, tuberculosis, leprosy, candidiasis, dermatitis, gonorrhea, malaria, scurfy affection, kidney and liver disorders (Batawila et al., 2005; Masoko \& Eloff, 2005; Fyhrquist, 2007; Kamtchouing et al., 2006; Gupta, 2012). Various colors of dyes utilized for many industrial productions were obtained from bark, root, leaf and fruit extracts and utilized for many industrial productions (Dalziel \& Hutchinson, 1937; Errington \& Chisumpa, 1987). Recently, in Egypt, biological studies on the leaves revealed numerous activities in vivo and in vitro studies; included antioxidant, anti-inflammatory, anti-diabetic, anti-ulcer, anti-hyperlipidemic, anti-microbial anti-cancer, anti-parasitic, hepatoprotective and cardioprotective activities (Fahmy et al., 2015).

In the recent past years, the leaf anatomical characters in the genus Terminalia (lamina and petiole) have been studied by many authors (Tilney, 2002; Ingle \& Dhabe, 2011, 2015; Akinsulire et al., 2018) for the identification of the relationships between its species.

In Egypt, Terminalia is represented by nine cultivated species (Sickenberger, 1901; Muschler
1912; Hamdy et al., 2007; Hamdy, 2010; Fahmy et al., 2015).

Due to the taxonomic conflict of the genus Terminalia and the difficulty in the identification of some of its species morphologically. Moreover, there is no comprehensive coverage of genus Terminalia in Egypt that distinguishes between different species anatomically, despite of its medicinal importance. Therefore, this research therefore set out to define the leaf (lamina and petiole) anatomical characters of the nine species of the genus Terminalia in Egypt as bases for the authentication and the discrimination among species.

\section{Material and Methods}

Ten fresh samples for each species were collected from different botanical gardens in Cairo and Giza Governorates, compared with authenticated materials kept in Cairo University Herbarium (CAI), identified (Table 1) then fixed in Formalin, Glacial Acetic acid (FAA) then 70\% ethyl alcohol. The transverse sections of leaves and petioles were cut using Reichert Sliding Microtome at a thickness of 8-10 microns. These sections were stained in Safranin for 3-5min, rinsed thoroughly in water to remove excess stain and counterstained in Light green solution for 3-5 min. The sections were again washed with water and treated in a series of ethanol dilution $50 \%, 70 \%, 80 \%, 90 \%$ and $100 \%$ to enhance the dehydration process. After dehydration, sections were transferred into absolute xylene to remove any remaining trace of water and ethanol. These made sections clearer and prevented the cloudiness of the slides. Sections were therefore mounted in Canada balsam on a clean glass slides for light microscopy.

Sections were investigated with light microscope; Olympus BX51. Photomicrographs were taken using photomicroscope; Olympus DP12 in the Central Laboratory, Geology Department, Faculty of Science, Cairo University, Egypt.

In this work, anatomical characters were the basis to separate the taxa, including petiole and leaf outline, epidermal feature, vascular pattern, the occurrence of cortical and pericycle fibers, presence / absence of crystals and trichomes in addition to the shape of main vascular bundle and number of accessory vascular bundles. 
TABLE 1. The localities of collected specimens, geographic coordinates and the date of collection of the investigated Terminalia species, kept at Cairo University Herbarium (CAI).

\begin{tabular}{|c|c|c|c|c|}
\hline $\mathbf{N}$ & Species & Locality & $\begin{array}{l}\text { Geographic } \\
\text { coordinates }\end{array}$ & Date of collection \\
\hline 1 & $\begin{array}{l}\text { T. arjuna (Roxb. ex DC.) } \\
\text { Wight \& Arn. }\end{array}$ & Giza: Zoological garden & $\begin{array}{l}30^{\circ} 01^{\prime} 24.7^{\prime \prime} \mathrm{N} \\
31^{\circ} 12^{\prime} 40.6^{\prime \prime} \mathrm{E}\end{array}$ & 7 Nov. 2016 \\
\hline 2 & T. bellirica (Gaertn.) Roxb. & Giza: Zoological garden & $\begin{array}{l}30^{\circ} 01^{\prime} 27.4 ” \mathrm{~N} \\
31^{\circ} 12^{\prime} 52.7^{\prime \prime} \mathrm{E}\end{array}$ & 7 Nov. 2016 \\
\hline 3 & T. bentzoe (L.) L. f. & Giza: Zoological garden & $\begin{array}{l}30^{\circ} 01^{\prime} 34.0 \prime \prime \mathrm{N} \\
31^{\circ} 12^{\prime} 46.0^{\prime \prime} \mathrm{E}\end{array}$ & 7 Nov. 2016 \\
\hline 4 & T. brownii Fresen. & Giza: Mazhar botanical garden & $\begin{array}{l}30^{\circ} 03^{\prime} \mathrm{N} \\
31^{\circ} 08^{\prime} \mathrm{E}\end{array}$ & 10 Dec. 2016 \\
\hline 5 & T. catappa $\mathrm{L}$. & Giza: Orman botanical garden & $\begin{array}{l}30^{\circ} 01^{\prime} \mathrm{N} \\
31^{\circ} 12^{\prime} \mathrm{E}\end{array}$ & 7 Nov. 2016 \\
\hline 6 & T. laxiflora Engl. \& Diels & Cairo: El Zohriya garden & $\begin{array}{l}30^{\circ} 02^{\prime} \mathrm{N} \\
31^{\circ} 13^{\prime} \mathrm{E}\end{array}$ & 16 Nov. 2016 \\
\hline 7 & T. mantaly H. Perrier & Giza: Mazhar botanical garden & $\begin{array}{l}30^{\circ} 03^{\prime} \mathrm{N} \\
31^{\circ} 08^{\prime} \mathrm{E}\end{array}$ & 10 Dec. 2016 \\
\hline 8 & T. muelleri Benth. & Giza: Zoological garden & $\begin{array}{l}30^{\circ} 01^{\prime} 35.2^{\prime \prime} \mathrm{N} \\
31^{\circ} 12^{\prime} 52.4^{\prime \prime} \mathrm{E}\end{array}$ & 7 Nov. 2016 \\
\hline 9 & $\begin{array}{l}\text { T. myriocarpa Van Heurck } \\
\text { and Mull. Arg. }\end{array}$ & Giza Zoological garden & $\begin{array}{l}30^{\circ} 01^{\prime} 34.8^{\prime \prime} \mathrm{N} \\
31^{\circ} 12^{\prime} 46.0^{\prime \prime} \mathrm{E}\end{array}$ & 7 Nov. 2016 \\
\hline
\end{tabular}

Terminology of the anatomical characters of leaf and petiole was described according to Metcalfe \& Chalk (1950), Tilney (2002) and Akinsulire et al. (2018).

In order to conduct which species are similar or dissimilar to each other, we use the clustering analysis of Multi-Variate Statistical Package version $3.13 \mathrm{~g}$. The matrix of the 9 studied species with the investigated 24 anatomical characters is subjected to the clustering method (UPGMA) with the average similarity distance. All categorical characters are transformed into binary characters $(0,1)$ in order to allow the use of cluster analysis techniques. This is followed by generalization of an artificial key depending on the anatomical characters investigated.

\section{Results}

Terminalia petiole in transverse section

The outline was more or less spherical, triangular or cave-shaped. Epidermis covered with very thin to rarely thick cuticle and simple, unicellular combretaceous trichomes, cells of epidermis square to more or less papillate. Hypodermis, if present, single layered formed of circular to polygonal cells. Cortex differentiated into outer and inner regions; outer collenchymatous and parenchymatous and inner collenchymatous (the collenchyma varies between angular and lamellar) throughout. Vascular system is either amphiphloic siphonostele, with outer and inner phloem continuous (Plate 1; F) or ectophloic siphonostele, with outer phloem only (Plate 2; L); lysigenous ducts 0-5 present in inner phloem, either solitary located centrally or in groups extending along the xylem length, sclerenchyma scares present. Accessory vascular bundles 2 to 3 similar or dissimilar. Calcium oxalate crystals (druses) rare to abundant occurring in cortex, phloem, rarely in bundle sheath (Plates 1, 2, 3). 


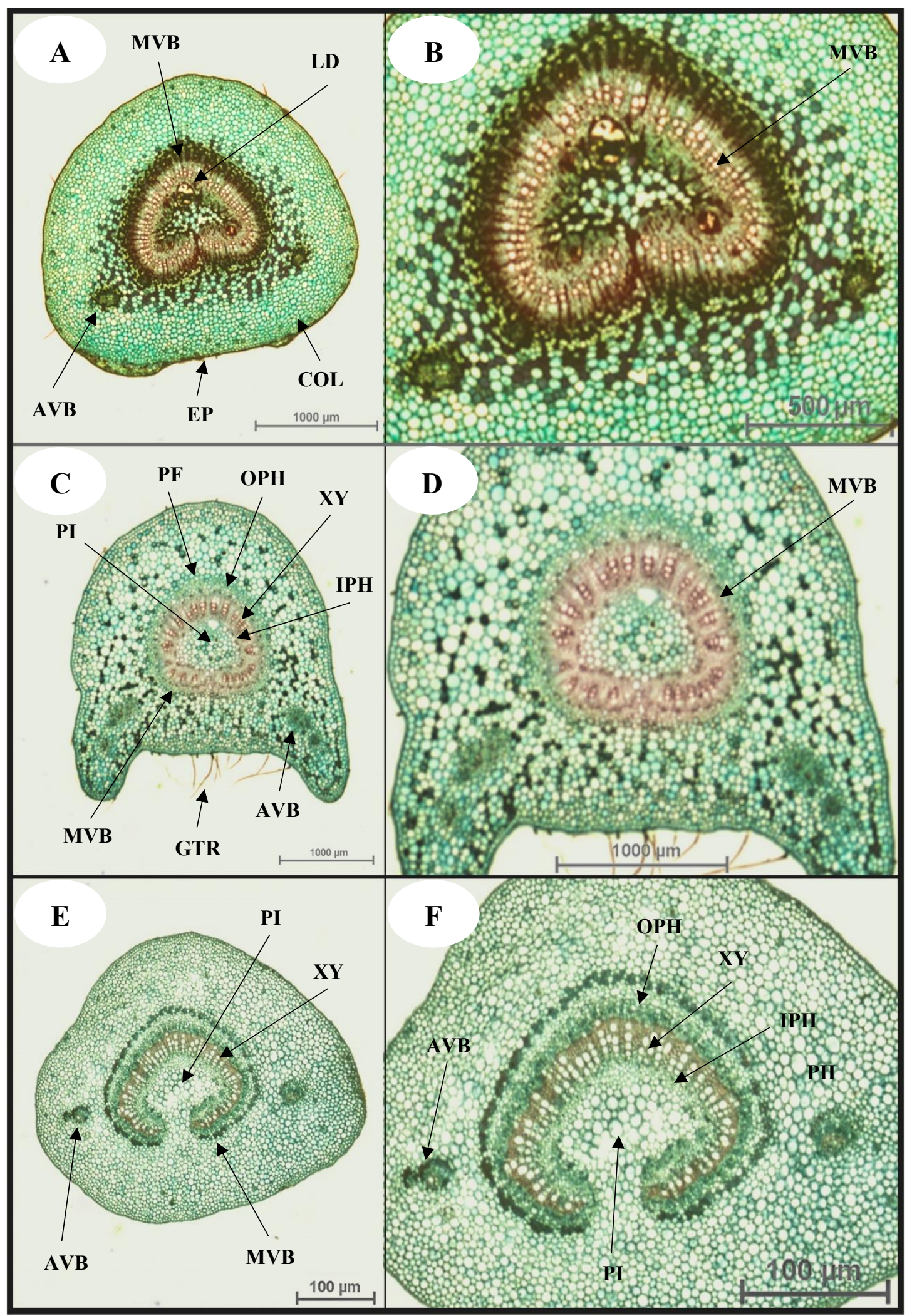

Plate 1. Transverse section of petiole in Terminalia species; A \& B: T. arjuna, C \& D: T. bellerica, E \& F: T. bentzoe $[\mathrm{AVB}=$ Accessory vascular bundle, $\mathrm{EP}=$ Epidermis, $\mathrm{COL}=\mathrm{Collenchyma}, \mathrm{LD}=\mathrm{Lysigenous} \mathrm{duct,} \mathrm{MVB}=$ Main vascular bundle, $\mathbf{P A R}=$ Parenchyma, $\mathbf{P I}=$ Pith, $\mathbf{P F}=$ Pericyclic Fibers, $\mathbf{T R}=$ Trichome $]$. 


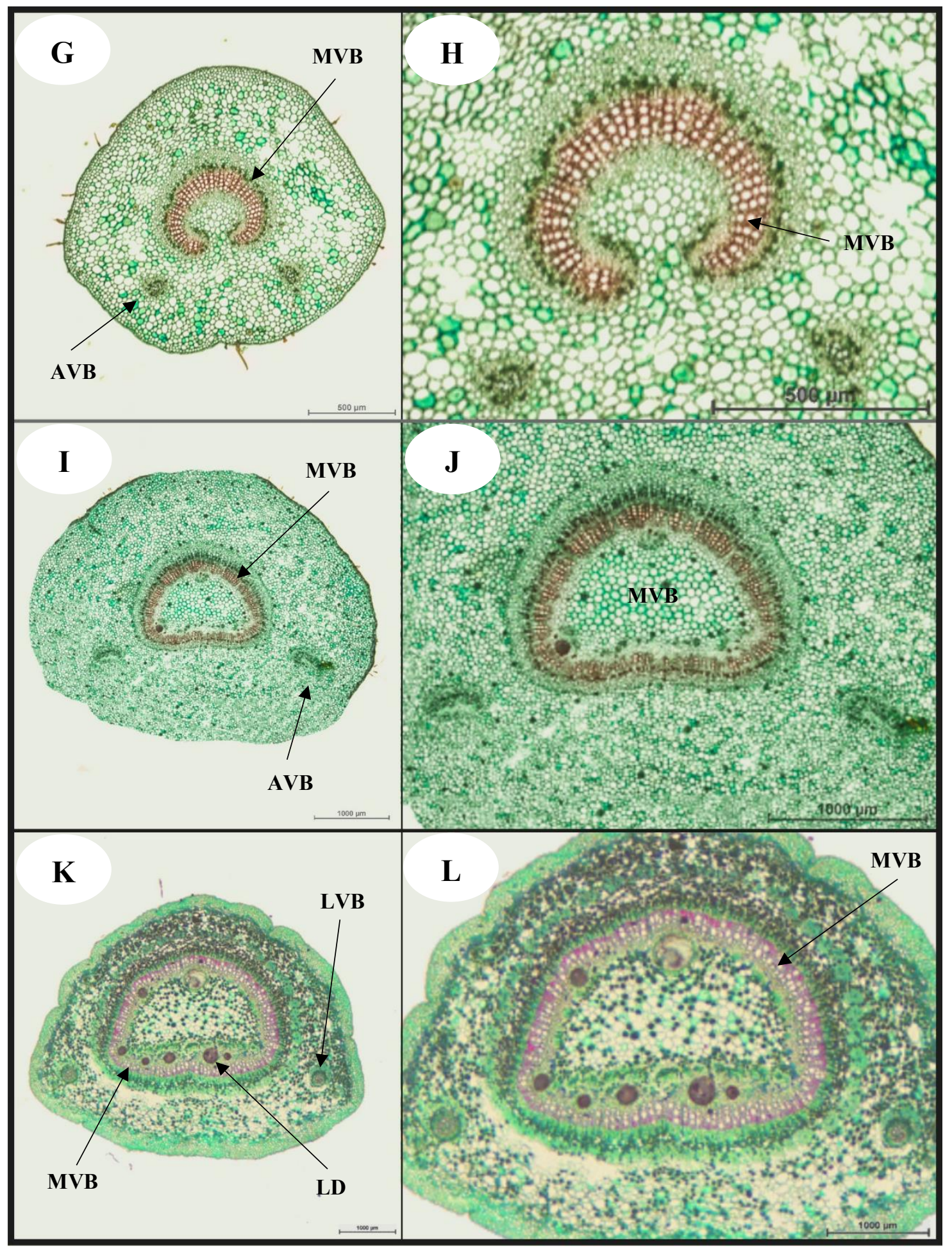

Plate 2. Transverse section of petiole in Terminalia species; G \& H: T. brownii, I \& J: T. catappa, K \& L: T. laxiflora $[\mathrm{AVB}=$ Accessory vascular bundle, $\mathrm{LD}=$ Lysigenous duct, $\mathrm{MVB}=$ Main vascular bundle $]$. 


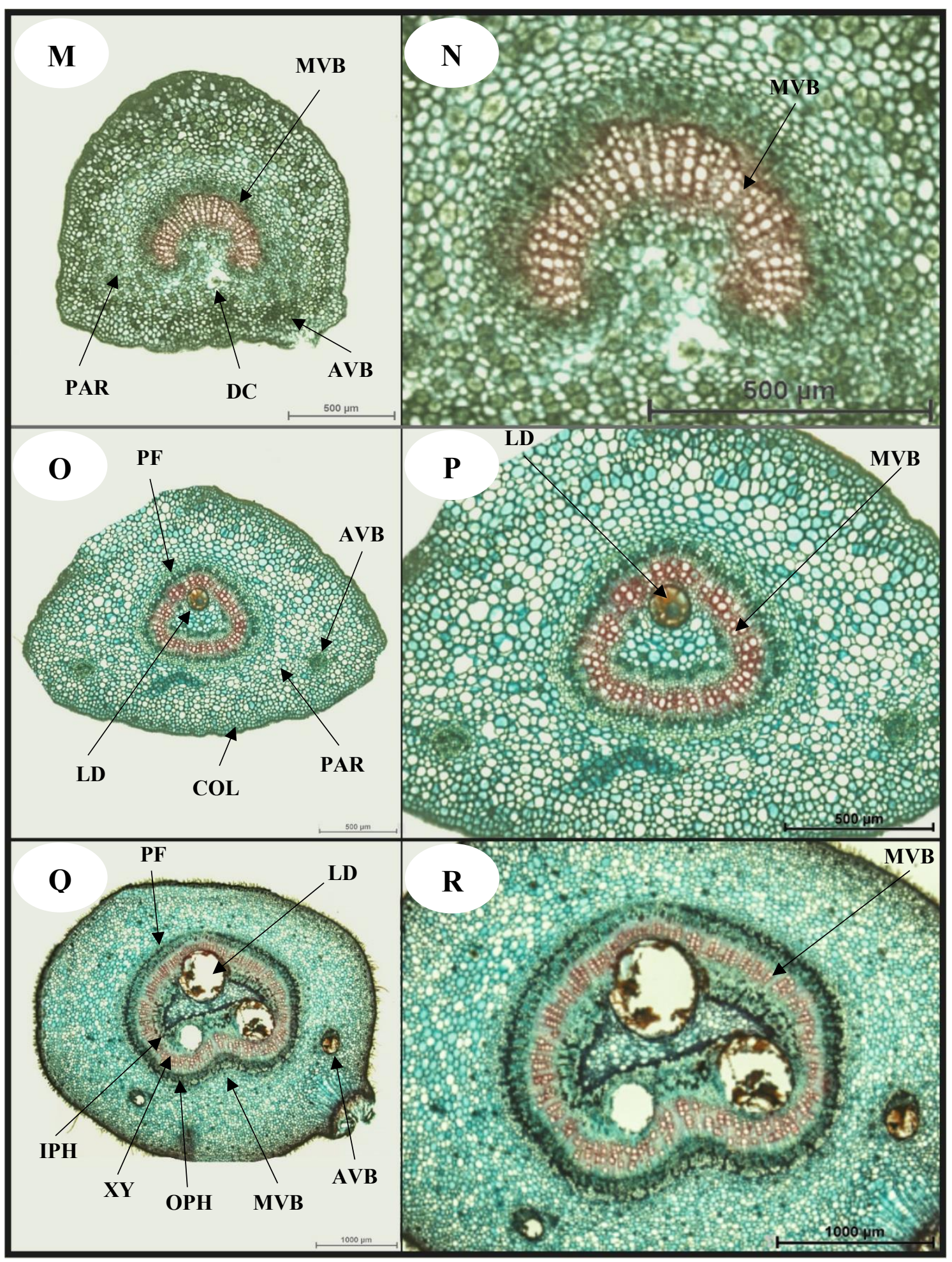

Plate 3. Transverse section of petiole in Terminalia species; M \& N: T. mantaly, O \& P: T. muelleri, Q \& R: T. myriocarpa $[\mathrm{AVB}=$ Accessory vascular bundle, $\mathrm{COL}=$ Collenchyma, $\mathrm{DC}=$ Druses, $\mathrm{IPH}=$ Inner phloem, $\mathrm{LD}=$ Lysigenous duct, $\mathrm{MVB}=$ Main vascular bundle, $\mathrm{OPH}=$ Outer phloem, $\mathbf{P A R}=$ Parenchyma, $\mathbf{P F}=\mathbf{P e r i c y c l e}$ fibers, $\mathrm{XY}=$ Xylem].

Egypt. J. Bot. 60 , No. 3 (2020) 


\section{Terminalia leaf in transverse section}

Leaf blade dorsiventral, hairs present of combretaceous type. Epidermis covered with very thin to medium cuticle layer on both surfaces, 1-layered with square to periclinal elongated cells (Plate 4; C); outer periclinal cell walls flattened on the upper surface and flattened to slightly convex on the lower surface or often ridged, usually strongly convex often appearing somewhat papillae over larger vascular bundles, rarely mucilaginous. Upper epidermal cells usually conspicuously larger than lower ones but occasionally similar, outer periclinal cell walls especially on adaxial surface often conspicuously cutinized but minute striate on the surface, inner periclinal and anticlinal cell walls always slightly cutinized. Mesophyll usually differentiated into palisade and spongy parenchyma; with palisade cells usually markedly elongated, 1-layered, small tubular extensions interconnecting cells frequently very conspicuous; spongy parenchyma, 3-6 layered, cells oval polygonal and irregular, in T. laxiflora, the mesophyll was formed of only 3 rows of palisade layer. Vascular bundles collateral in small veins or bicollateral in large veins, sclerenchyma nearly always associated with phloem only but rarely with phloem and xylem, surrounded by a bundle sheath formed of parenchyma cells (Plate 5; J).

Druses crystals always present, in varying numbers and sizes, usually very large in idioblasts, palisade parenchyma, spongy parenchyma, and at the junction of palisade and spongy parenchyma. Midrib area variously raised or flattened. Cuticle was very thin to medium thick. Epidermis 1-layered usually followed by a single hypodermal layer (Plate 5; K); cells square to anticlinal elongated with the outer periclinal cell walls mostly slightly convex on the upper surface but usually strongly convex often appearing almost papillae on periclinal cell walls. Midrib formed of one or two type of cells, often forming a continuous collenchymatous layer usually more than one cell thick adjacent to adaxial epidermis tissue followed by 1-6 thin wall parenchymatous layers. Central vascular bundle was conjoint; open bicollateral endarch vascular bundle of different shape and size (Plate 6; P). Sclerenchyma fibers combined with external phloem or external and internal phloem. Patches of fibers interrupted with tanniniferous cells in complete or incomplete bands. Mucilage ducts if present, usually one or up to three towards the inside of the inner xylem. Druses crystals frequently present in collenchyma, parenchyma and phloem accessory vascular bundle, if present, one or two equal or unequal situated on either side towards the epidermis, conjoint, concentric, closed and collateral type (Plates 4, 5, 6).

Table 2 shows the 24 investigated anatomical characters of the leaf and petiole of Terminalia species in Egypt. These characters are distinguishable and used to construct the following cluster.

The goal of cluster analysis is to group a collection of objects in such a way that characters in the same group are more similar to one another than characters in other groups. The hierarchical structure of UPGMA with the average similarity distance (Fig. 1) helps in the generalization of the artificial key adopted below.

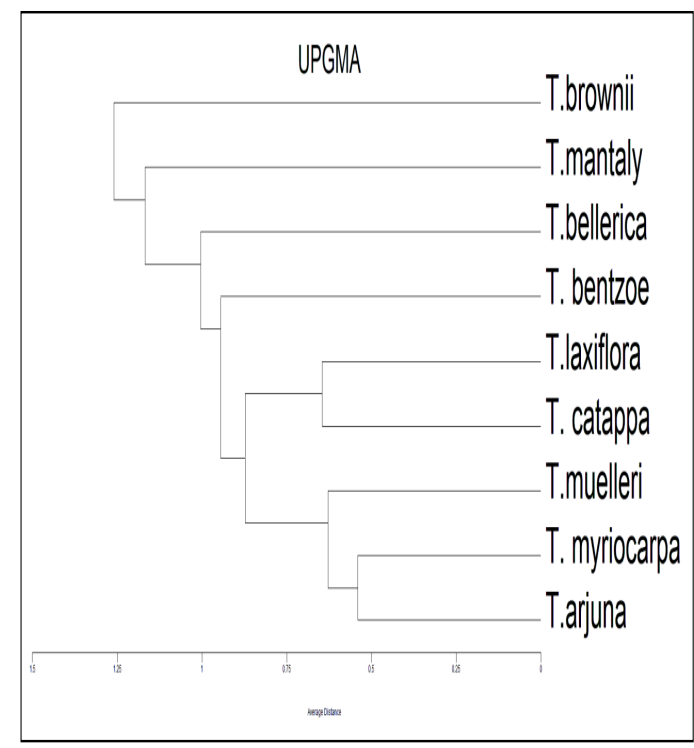

Fig. 1. The cluster analysis of the nine Terminalia species based on the investigated anatomical characters (Table 2). 


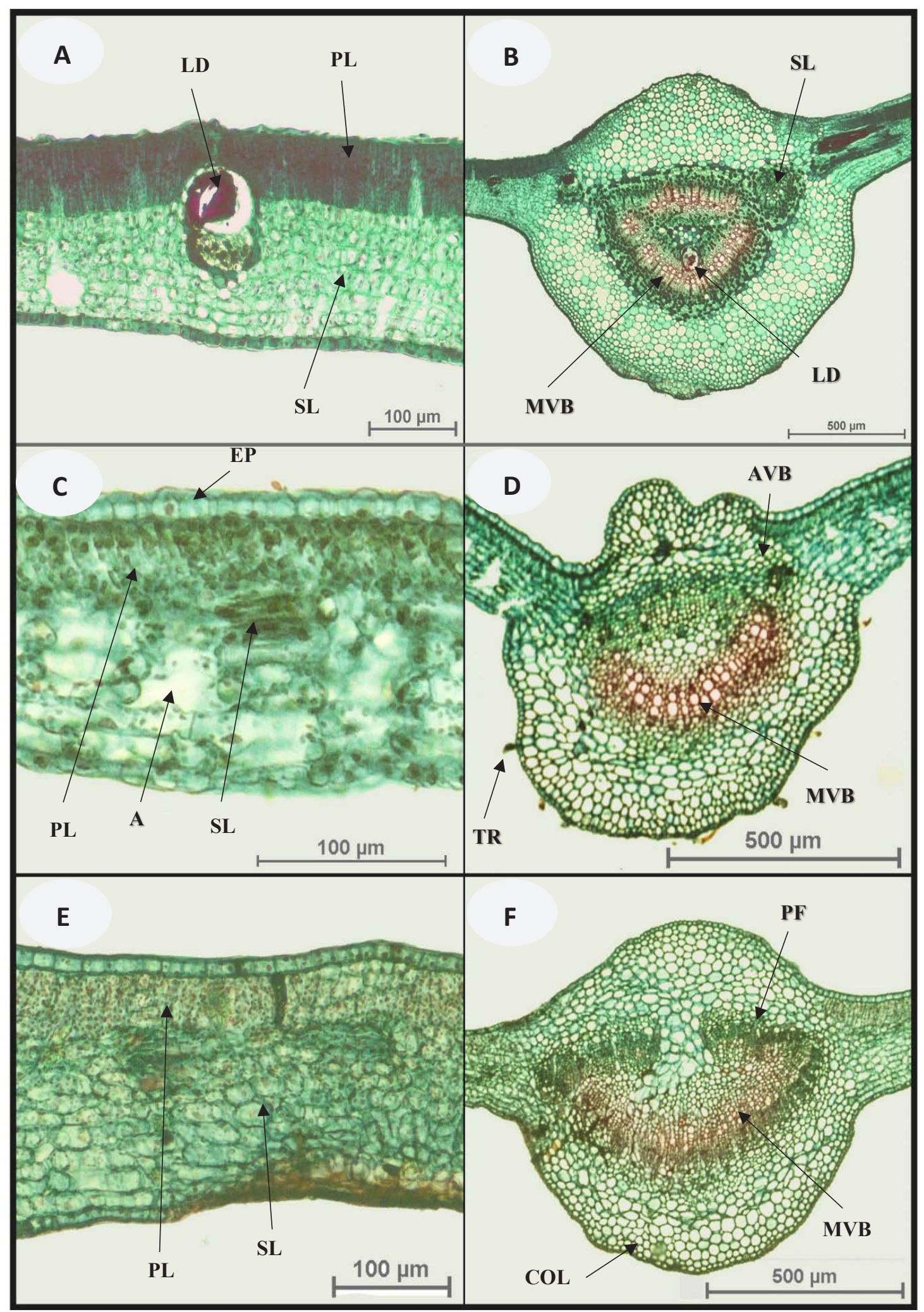

Plate 4. Transverse section of midrib and lamina in Terminalia species; A \& B: T. arjuna, C \& D: T. bellerica, $\mathrm{E} \& \mathrm{~F}:$ T. bentzoe $[\mathrm{AC}=$ Air cavity, $\mathrm{AVB}=$ Accessory vascular bundle, $\mathrm{COL}=$ Collenchyma, $\mathrm{EP}=\mathrm{Epidermis,} \mathrm{LD}=$ Lysigenous duct, $\mathrm{MVB}=$ Main vascular bundle, $\mathbf{P A R}=\mathbf{P a r e n c h y m a}, \mathbf{P F}=$ Pericyclic fibers, $\mathbf{P L}=\mathbf{P a l i s a d e}$ layer, $\mathrm{SL}=$ Spongy layer, $T R=$ Trichome $]$. 


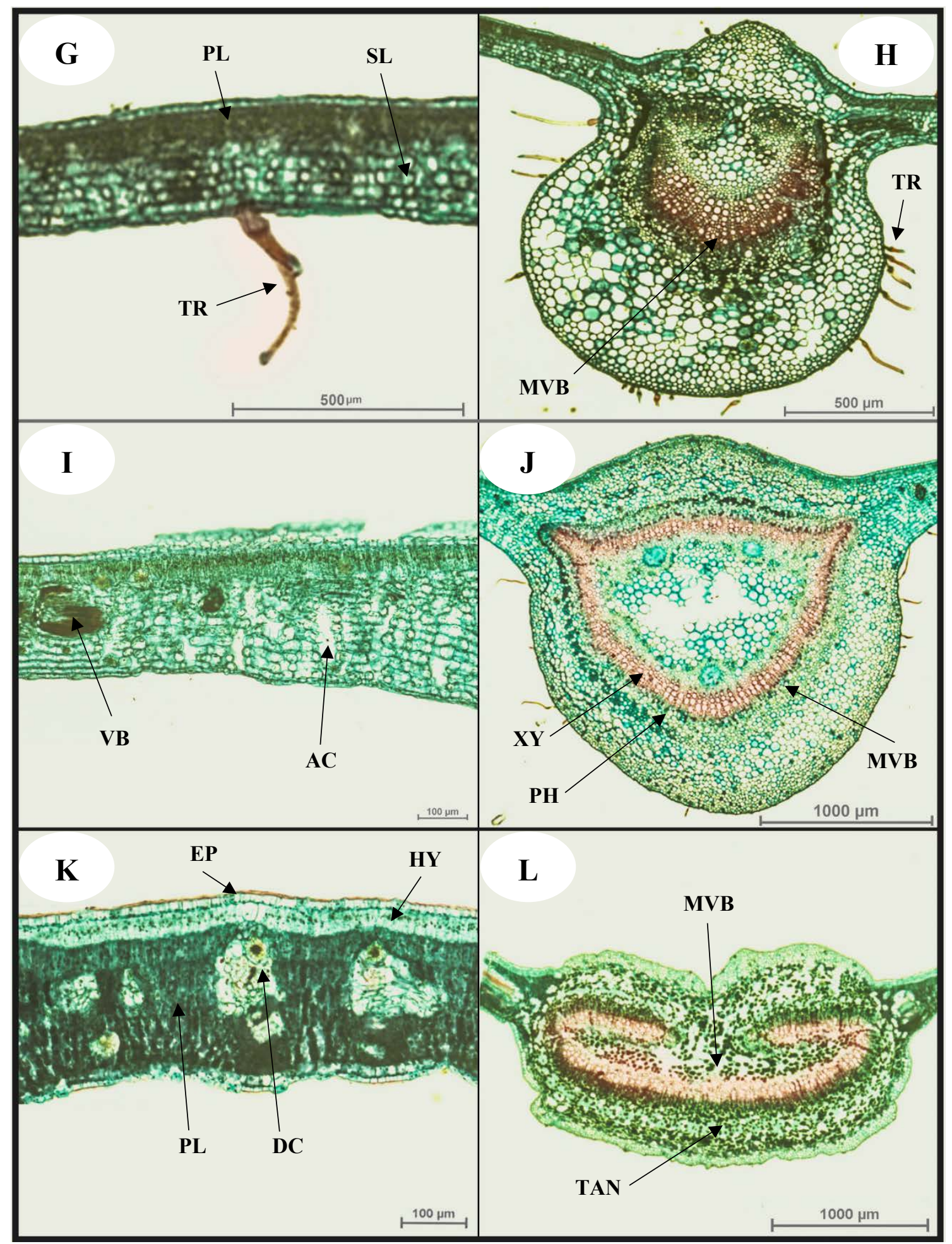

Plate 5. Transverse section of midrib and lamina in Terminalia species; G \& H: T. brownii, I \& J: T. catappa, K \& L: T. laxiflora $[\mathrm{AC}=$ Air cavity, $\mathrm{EP}=$ Epidermis, $\mathrm{HY}=$ Hypodermis, $\mathrm{DC}=$ Druse crystals, $\mathrm{LD}=\mathrm{Lysigenous}$ duct, $\mathrm{MVB}=$ Main vascular bundle, $\mathrm{PH}=\mathrm{Phloem}, \mathrm{PL}=$ Palisade layer, $\mathrm{SL}=$ Spongy layer, $\mathrm{TAN}=$ Tannins, $\mathrm{TR}=\mathrm{Trichome}, \mathrm{VB}=$ Vascular bundle, $\mathrm{XY}=\mathrm{Xylem}]$. 


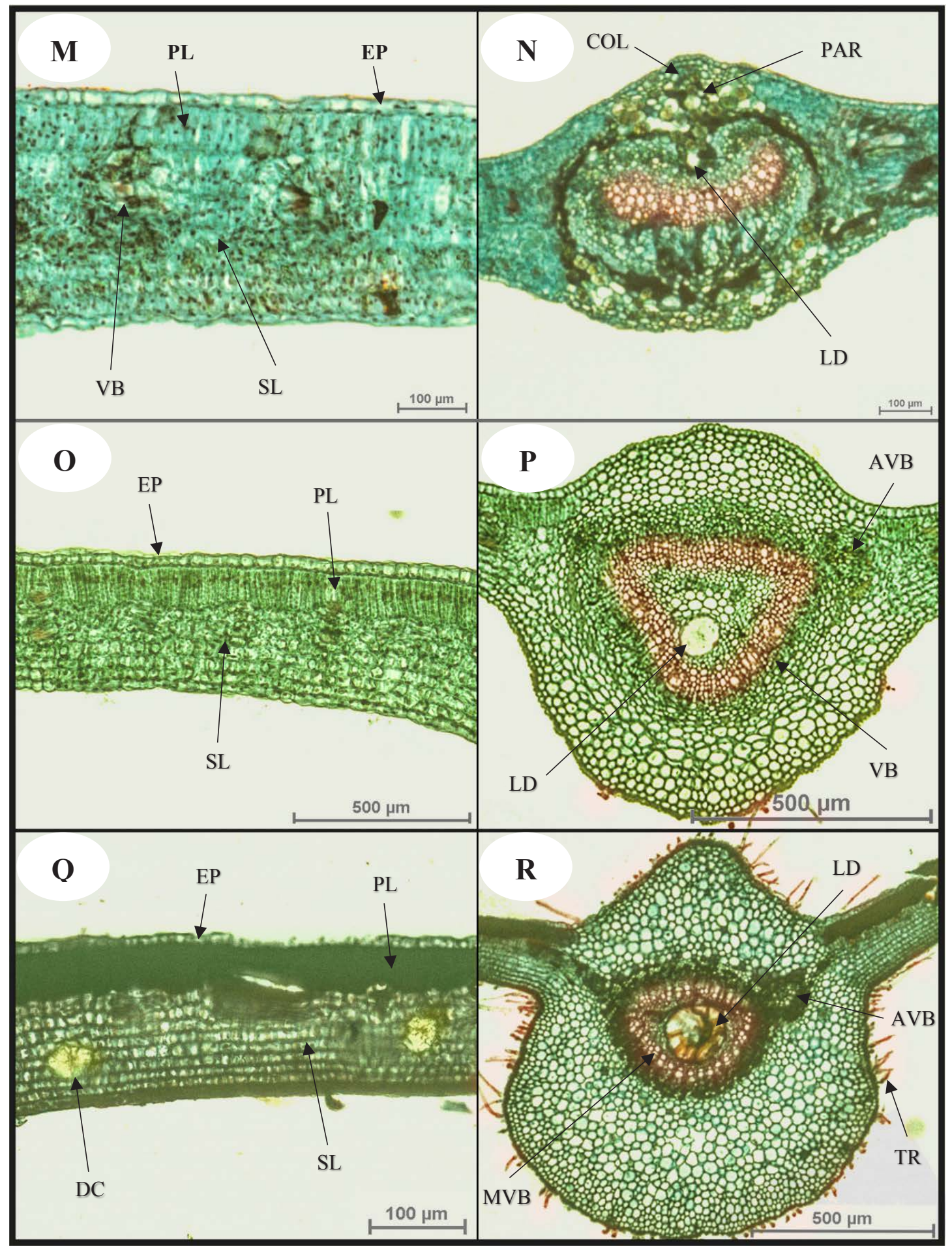

Plate 6. Transverse section of midrib and lamina in Terminalia species; $\mathrm{M} \& \mathrm{~N}:$ T. mantaly, $\mathrm{O} \& \mathrm{P}:$ T. muelleri, $\mathrm{Q} \&$ R: T. myriocarpa $[\mathrm{AVB}=$ Accessory vascular bundle, $\mathrm{EP}=$ Epidermis, $\mathrm{COL}=$ Collenchyma, $\mathrm{DC}=$ Druse crystals, $\mathbf{L D}=$ Lysigenous duct, $\mathrm{MVB}=$ Main vascular bundle, $\mathbf{P L}=$ Palisade layer, $\mathbf{P A R}=$ Parenchyma, $\mathbf{S L}=\mathbf{S p o n g y}$ layer, $\mathrm{TR}=$ Trichome, $\mathrm{VB}=$ Vascular bundle]. 
TABLE 2. The anatomical characters of the nine investigated species of Terminalia in Egypt.

\section{Characters
Petiole outline: Ovate (1), triangular (2), cat face (3), cave (4)
Petiole hypodermis: Present (1), absent (2)
Petiole ground tissue ratio - Collenchyma/Parenchyma: 1:1
(1), 1:2 (2), 1:3 (3), 1:4 (4), 2:3(5)}

Petiole lenticels \& Trichomes: Present (1), absent (2)

Petiole main vascular bundle shape: Heart-shaped (1), closed triangular (2), open triangular (3), crescent-shaped (4)

Petiole bundle sheath sclerenchyma cells: Continuous ring (1), patches (2)

Petiole accessory vascular bundles distribution: One on each side (1), two on each side (2), one in one side \& two on other side (3)

Petiole accessory vascular bundle type: Primitive (1), open collateral (2)

Petiole lysigenous ducts: Present (1), absent (2)

Petiole lysigenous ducts number: Zero (1), two (2), more than two (3)

Petiole tannins: Present (1), absent (2)

Petiole crystals: Few (1), abundant (2)

Leaf mesophyll ratio-palisade/spongy: 1:2 (1), 1:3 (2), 1:4 (3)

Leaf midrib region: One type of cells (1), two types of cells (2)

Leaf main vascular bundle shape: Triangular (1), open mouth (2), cat face (3), crescent (4), open heart (5)

Leaf main vascular bundle size: Small (1), medium (2), large (3)

Leaf accessory vascular bundle: Present (1), absent (2)

Leaf number of accessory vascular bundles in each side: Zero (1), two (2), more than two (3)

Leaf vascular bundle of small veins: Present (1), absent (2)

Leaf crystals: Few (1), abundant (2)

Leaf shape of upper epidermis: Rectangular (1), papillose (2)

Leaf length of palisade in mesophyll: $<50 \mu \mathrm{m}(1),>50 \mu \mathrm{m}(2)$

Leaf length of Spongy in mesophyll: $<70 \mu \mathrm{m}(1), 70>\mu \mathrm{m}(2)$

Leaf bundle sheath shape: Patches (1), continuous ring (2)

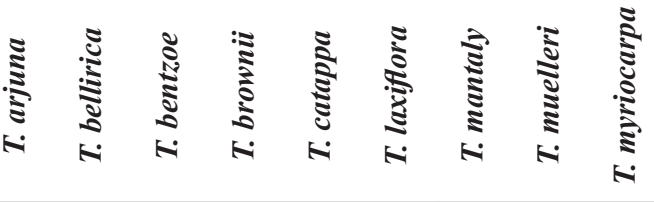
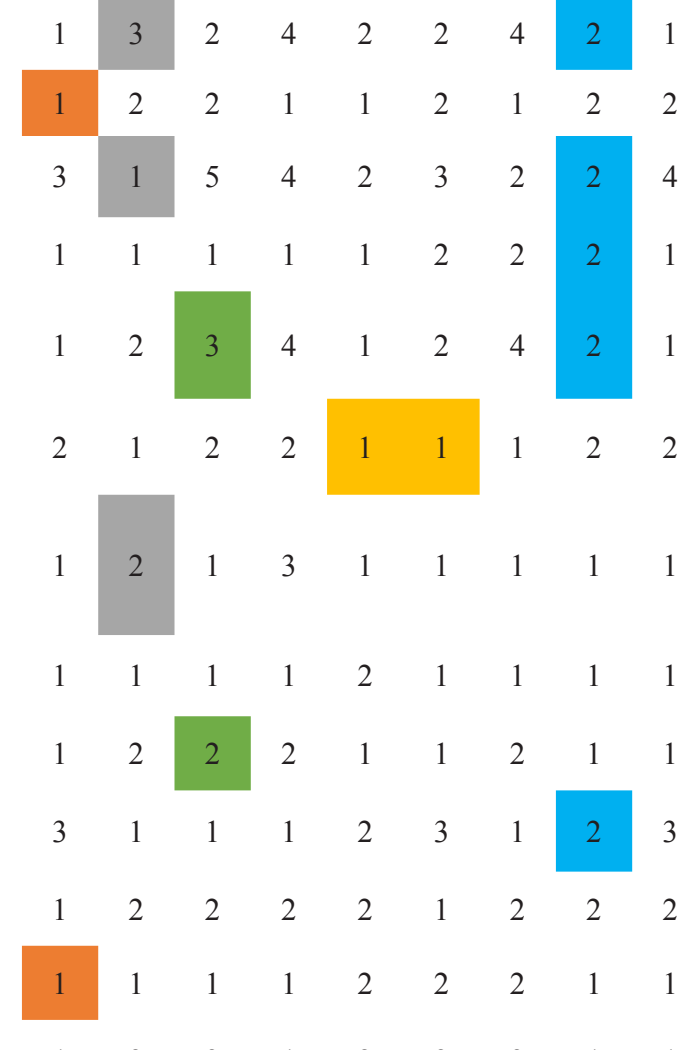

$\begin{array}{lllllllll}1 & 3 & 3 & 1 & 2 & 3 & 3 & 1 & 1\end{array}$

$\begin{array}{lllllllll}2 & 2 & 2 & 2 & 2 & 2 & 1 & 2 & 2\end{array}$
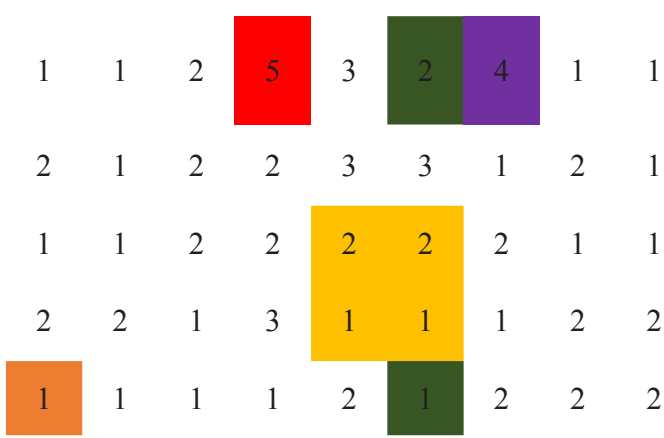

\begin{tabular}{lllllllll}
2 & 1 & 1 & 2 & 1 & 1 & 2 & 1 & 1 \\
1 & 2 & 1 & 1 & 1 & 1 & 1 & 1 & 1 \\
2 & 1 & 1 & 1 & 1 & 1 & 1 & 2 & 1 \\
2 & 1 & 2 & 1 & 2 & 2 & 2 & 2 & 2 \\
1 & 2 & 2 & 1 & 2 & 2 & 2 & 1 & 1 \\
\hline
\end{tabular}


Artificial key based on the petiole and leaf anatomical characteristics

I- Petiole shape in TS cave-shaped.......................1 1a- Main vascular bundle in leaf open heartshaped ...................................................T. brownii 1b- Main vascular bundle in leaf crescent-shaped....................................T. mantaly

II-Petiole shape in TS cat face. T. bellerica

III-Petiole shape in TS triangular. . .2 2a- Main vascular cylinder in petiole, open triangular (amphiphloic siphonostele).T. bentzoe 2b- Main vascular cylinder in petiole, closed triangular or heart-shaped (ectophloic siphonostele) ....3

3a- Bundle sheath sclerenchyma cells in petiole form a continuous ring ....4 3b- Bundle sheath sclerenchyma cells in petiole form separate patches T. muelleri 4a- main vascular bundle shape cat face. T. catappa

4b- Leaf main vascular bundle shape open mouth T. laxiflora

IV-Petiole shape in TS ovate. . .5 5a- Leaf vascular bundle in small veins and petiole hypodermis are present..............T. arjuna 5b- Leaf vascular bundle in small veins and petiole hypodermis are absent .....T. myriocarpa

\section{Discussion}

Many researchers in various plant taxa used leaf anatomy for taxonomic purposes (Illo, 1995; Adedeji, 2004; Adedeji \& Illoh, 2004; Okeke et al., 2015; Rodríguez et al., 2016). Among the most anatomical features, the leaf and petiole anatomy provide diversity of characters which could be used for taxonomic purposes. In addition, the leaf the most diverse organ of angiosperms, and their anatomical variation frequently correlate closely with generic and common, often phylogenetic lines (Carlquist, 1961).

Anatomical characters, along with other characters, have been considered important in providing additional features; they are typically of taxonomic significance in plant identification and classification. Howard (1979) and Khatijah et al. (1992) have reported that anatomical characteristics often indicate relationship between species and often classify the position of the species, and the data obtained from anatomy can be used extensively for taxonomic and phylogenetic elucidation (Illoh \& Inyang, 1998).

Many anatomical characters of leaf and petiole can be investigated as taxonomic tools in plant identification and differentiation between the taxa. The epidermal cells in the investigated species are arranged irregularly that are polygonal, isodiametric or elongated in various directions. The anticlinal epidermal walls are sinuous, undulating, straight or arched, characteristic as cited by Ekeke \& Agbagwa (2015) for T. catappa. The presence of a thin cuticle helps protection against multiple stress factors including dehydration (Gonzalez, 2002). The epidermal characteristics have been utilized for taxonomic specification of taxa at the genus and family levels (Van Cotthem, 1970; Paliwal et al., 1980; Naidu \& Shah, 1981; Das, 2002; Agbagwa \& Okoli, 2005 \& 2006; Amaral \& Mello-Silva, 2008). Particularly, Ramassamy \& Kannabiran (1994) used the epidermal characteristics as stomata and trichome types for taxonomic considerations of some Terminalia species in India. There is significant diversity observed in the epidermal area among the investigated species. Therefore, the epidermal characters were utilized for differentiation between species.

The structure of the petiole is significant for the discrimination of taxa and has considerable taxonomic importance in many genera, once it is less affected by environmental changes (Metcalfe \& Chalk, 1950); the shape and type of vascular cylinder in the petiole were remarkable characters (Ayensu, 1968) as the morphologic separation is hard within some species (Leme \& Scremin-Dias, 2014). Particularly, Akinsulire et al. (2018) utilized the shape of the vascular cylinder and the arrangement of the accessory vascular bundles of the petiole as diagnostic characters for the separation between five species of Terminalia in southwest Nigeria. He placed T. mantaly and T. catapa in one group based on their quantitative leaf anatomical characters.

The vascular cylinder in petiole in the genus Terminalia is siphonostele. Most of the higher vascular plants display centered steles with a pith. The pith remains surrounded by xylem, which in 
turn is surrounded by phloem on the peripheral side (ectophloic siphonostele) or both in and out (amphiphloic siphonostele). Those steles are called siphonosteles. Ectophloic siphonostele has a continuous cylinder of the vascular tissues in its primitive form. The advanced form consists of a bundling network.

The secretory structure including ducts can also be used as diagnostic parameters for the separation between the species (Milan et al., 2006) and identification of the genera (Castro et al., 1997).

Amongst the studied species of Terminalia, anatomical characters of leaf and petiole seem to be of high taxonomic value in plant identification. Twenty four anatomical characters that have significant anatomical diversity have been investigated; in leaf; type of mesophyll, length of palisade tissue, number and size of the main and accessory vascular bundles, presence or absence of vascular bundles in small veins as well lysigenous ducts and crystals, while in petiole: the type and shape of the vascular cylinder, the number and distribution of the accessory vascular bundles, types of bundle sheath, number of lysigenous ducts, etc. All these characters help to differentiate the nine Terminalia species and help to create an artificial key.

The main vascular cylinder in the petiole has various types and shapes; we recognize crescent shape with amphiphloic siphonostele in T. brownii and T. mantaly, while the other seven species viz: T. arjuna, T. muelleri, T. bellerica, T. bentzoe, T. catappa, T. myriocarpa and $T$. laxiflora varies between heart or triangular shape and ampliphloic or ectophloic siphonostele.

The main vascular bundle in the leaf was of diagnostic characters, it takes an open-heart shape in T. brownii (Plate 2; G \& H) and a crescent shape in $T$. mantaly (Plate $3 ; \mathrm{M} \& \mathrm{~N}$ ). Akinsulire et al. (2018) described the vascular bundle of $T$. mantaly as deeply crescent form or lunar-shaped. Seema et al. (2015) described the vascular bundle of the mature leaves of $T$. catappa as an arc-shaped.

Moreover, the distribution of accessory vascular bundles in the petiole of Terminalia play a great role as a diagnostic character, $T$. bellerica (Plate 1; C \& D) has two vascular bundles on each side of the petiole while the other 8 species have only one vascular bundle on each side. Presence, absence and number of lysigenous ducts in Terminalia petiole differentiate between the nine investigated species. Lysigenous ducts was absent in $T$. bellerica (Plate 1; C \& D), T. bentzoe (Plate1; E \& F), T. brownii (Plate 2; G \& $\mathrm{H})$ and T. mantaly (Plate $3 ; \mathrm{M} \& \mathrm{~N}$ ) while present with various number in T. arjuna (Plate 1; A \& B), T. muelleri (Plate 3; O \& P), T. catappa (Plate 2; I \& J), T. myriocarpa (Plate 3; Q \& R) and $T$. laxiflora (Plate 2; K \& L). It was two ducts in $T$. muelleri (Plate 3; O \& P) and T. catappa (Plate 2 ; I \& J), three ducts in T. arjuna (Plate 1; A \& B) and T. laxiflora (Plate 2; K \& L) and numerous ducts in T. myriocarpa (Plate 3; Q \& R).

The bundle sheath that surrounds the main vascular bundle in the petiole of Terminalia consists of sclerenchyma cells that can take different shapes. In both, T. catappa (Plate 2; I \& $\mathrm{J}$ ), and T. laxiflora (Plate 2; K \& L), the bundle sheath was in a continuous ring while in the others in separate patches.

T. catappa (Plate 2; I \& J / Plate 5; I \& J) and T. laxiflora (Plate 2; K \& L / Plate 5; K \& L) are more or less similar to each other in the leaf and petiole anatomical characters, but we can differentiate between them by the shape of the main vascular bundle in the leaf which takes a cat face shape in $T$. catappa (Plate 5; I \& J) and an open mouth shape in T. laxiflora (Plate 5; K \& L). In addition, trichomes and lenticels in petiole was absent in T. laxiflora but present in T. catappa.

The petiole outline of Terminalia species shows a great variation. We can recognize a triangular shape in T. muelleri (Plate 3; O \& P), T. bentzoe (Plate 1; E \& F), T. catappa (Plate 2; I \& J) and T. laxiflora (Plate 2; K \& L); but an ovate shape in T. arjuna (Plate 1; A \& B), T. brownii (Plate 2; G \& H) and T. myriocarpa (Plate 3; Q \& R).

T. arjuna (Plate 1; A \& B / Plate 4; A \& B) and T. myriocarpa (Plate 3; Q \& R / Plate 6; Q $\& \mathrm{R})$ are more or less similar in their leaf and petiole anatomical characters, however, we can differentiate between them by the presence of vascular bundle in the small veins in leaf and the hypodermis in petiole in T. arjuna and their absence in T. myriocarpa. 


\section{Conclusion}

The anatomical characteristics of the petiole and leaf described in this study are quite significant in the generic delimitation and differentiation of the studied members within genus Terminalia.

Conflict of interests: The authors certify that they have no affiliations with or involvement in any organization or entity with any financial interest or non-financial interest in the subject matter or materials discussed in this manuscript.

Authors contribution: N.W., R.H. and H.M. conceived of the presented idea. N.W. and R.H. developed the theory. R.H. and H.M. performed the measurements and processed the experimental data. A.S. performed the computations and verified the analytical methods. All authors discussed the results and contributed to the final manuscript.

Ethical approval: Not applicable.

\section{References}

Adedeji, O. (2004) Leaf epidermal studies of the species of Emilia Cass. (Senecioneae, Asteraceae) in Nigeria, Botanica Lithuanica, 10(2), 121-133.

Adedeji, O.A., Illoh, H.C. (2004) Comparative foliar anatomy of the genus Hibiscus Linn. in Nigeria. New Botanist, 31, 147-180.

Agbagwa, I.O., Okoli, B.E. (2005) Fruit epidermal micromorphology in the systematics of Abrus Adanson (Papilionaceae) in parts of West Africa. Asian Journal of Plant Sciences, 4, 652-659.

Agbagwa, I.O., Okoli, B.E. (2006) Leaf epidermal micromorphology in the systematics of Abrus (Papilionaceae) in parts of tropical West Africa. Asian Journal of Plant Sciences, 5, 41-49.

Akinsulire. O.P., Oladipo, O.T., Akinloye, A.J., Illoh, H.C. (2018) Structure, distribution and taxonomic significance of leaf and petiole anatomical characters in five species of Terminalia (L.) (Combretaceae: Magnoliopsida). Brazilian Journal of Biological Sciences, 5(10), 515-528.

Al-Mayah, A.R.A. (1983) The taxonomy of Terminalia (Combretaceae) and related genera. Ph.D. Thesis, University of Leicester.

Egypt. J. Bot. 60 , No. 3 (2020)
Amaral, M.M.D., Mello-Silva, R.D. (2008) Ontogenesis of stomata in Velloziaceae: Paracytic versus tetracytic? Brazilian Journal of Botany, 31, 529536.

Ayensu, E.S. (1968) Comparative vegetative anatomy of the Stemonaceae (Roxburghiaceae). Botanical Gazette, 129, 160-165.

Batawila, K., Kokou, K., Koumaglo, M., Gbeassor, M., De Foucalt, B., Bouchet, Ph., Akpagana, K. (2005) Antifungal activities of five Combretaceae used in Togolese traditional medicine. Fitoterapia, 76, 264 268.

Carlquist, S. (1961) "Comparative Plant Anatomy: A Guide to Taxonomic and Evolutionary Application of Anatomical Data in Angiosperms", Holt, Rinehart and Winston, New York, Biology Studies, 146p.

Clarke, C.B. (1878) Combretaceae. In: "The flora of British India", Hooker, J.D. (Ed.), pp. 443-461. Vol.2, L. Reeve \& Co., London.

Castro, M.M., Leitão-Filho, H.F., Monteiro, W.R. (1997) Utilização de estruturas secretoras na identificação dos gêneros de Asteraceae de uma vegetação de cerrado. Revista Brasileira de Botânica, 20, 163174.

Dalziel, J.M., Hutchinson, J. (1937) "Useful Plants of West Tropical Africa". Crown Agents, London, 612p.

Das, S. (2002) On the ontogeny of stomata and glandular hairs in some Indian mangroves. Acta Botanica Croatica, 61, 199-205.

Ekeke, C., Agbagwa, I.O. (2015) Epidermal Structures and Stomatal Ontogeny in Terminalia catappa L. (Combretaceae). International Journal of Botany, 11(1), 1-9.

Engler, A., Diels, L. (1900) In: "Monographien Afrikanischer Pflanzen Familien und Gattungen, IV. Combretaceae africanae (II) excluding Combretum", A. Engler (Ed.). W. Engelmann, Leipzig, 84p.

Errington, L., Chisumpa, S.M. (1987) "Natural Dyes of Zambia". Mission Press, Ndola Zambia.

Exell, A.W. (1954) Combretaceae. In: "Flora Malesiana", CGGJ Van Steenis (Ed.). Ser. 1, 4, pp. 533-628, Noordhoff-Kolff, Jakarta. 
Exell, A.W. (1978) Combretaceae. In: "Flora Zambesiaca", E. Launert E (Ed.), Vol.4, pp. 100183, Flora Zambesiaca Managing Committee, London.

Fahmy, N.M., Al-Sayed, E., Singab, A.N. (2015) Genus Terminalia: A phytochemical and Biological Review. Medicinal \& Aromatic Plants, 4(5), 1-8.

Fyhrquist, P.J. (2007) Traditional medicinal uses and biological activities of some plant extracts of African Combretum Loefl., Terminalia L. and Pteleopsis Engl. Species, Ph.D Thesis, 183p.

Gonzalez, A.M. (2002) Anatomia del vástago em especies selectas de plantas hidrófilas. "Flora del Iberá". Corrientes: EUDENE. 613p.

Griffiths, M.E. (1959) A revision of the African species of Terminalia. Botanical Journal of the Linnean Society, 55, 818-907.

Gupta, P.C. (2012) Biological and pharmacological properties of Terminalia chebula retz. (haritaki) An overview. International Journal of Pharmacy and Pharmaceutical Sciences, 4(3), 62-68.

Hamdy, R. (2010) Study of plant distribution in nine historic gardens in Egypt. Journal of Garden History, 38(2), 267-314.

Hamdy, R., Abd El Ghani, M.M., Youssef, T.L. (2007) The floristic composition of some historic gardens in the metropolitan of Cairo, Egypt. African Journal of Agriculture Research, 2(11), 610-648.

Heiden, H. (1893a) "Anatomische Charakteristik der Combretaceen". Botanisches Centralblatt, Vol. 55, pp.353-360, 383-391.

Heiden, H. (1893b) "Anatomische Charakteristik der Combretaceen". O. Uhlworm and F.G. Kohl, (Eds.), Botanisches Centralblatt, Vol. 56, pp. 1-12, 65-75, 129-136, 163-170, 193-200, 225-230. Cassel, verlag von Gebrüder Gotthelft.

Howard, R.A. (1979) The stem-node-leaf continuum of the Dicotyledonae. In: "Anatomy of the Dicotyledons", C.R. Metcalfe \& L. Chalk, L. (Eds.), pp. 76-87, $2^{\text {nd }}$ ed., Vol. 1, Clarendon Press, Oxford, UK,

Illoh, H.C. (1995) Foliar epidermis and petiole anatomy of four species of Celosia L. in Nigeria. Feddes
Repertorium, 106(1/2), 15-23.

Illoh, H.C., Inyang, U.E. (1998) Foliar epidermis and petiole anatomy in some Nigerian Solanum Linn. species in the sub-genus Leptostemon (Bitt) Dun. Glimpses in Plant Research, 12, 73-86.

Ingle, P., Dhabe, A. (2011) Pharmacognostic studies on Terminalia citrina (Gaertn) Roxb. ex Fleming. Pharmacognosy Journal, 3(20), 63-65.

Ingle, P., Dhabe, A. (2015) Anatomical investigation of Terminalia chebula Retz. Phytotaxonomy, 15, 5562.

Irvine, F.R. (1961) "Woody Plants of Ghana: With Special Reference to their Uses". Oxford University Press, London, UK., 868p.

Kamtchouing, P., Kahpui, S.M., Dzeufiet, P.D., T’edong, L., Asongalem, E.A., Dimoa, T. (2006) Anti-diabetic activity of methanol/methylene chloride stem bark extracts of Terminalia superba and Canarium schweinfurthii on streptozotocin-induced diabetic rats. Journal of Ethnopharmacology, 104, 306-309.

Khatijah, K.H, Cutle, D.R., Moore, D.M. (1992) Leaf anatomical studies of Eugenia L. (Myrtaceae) species from Malay Peninsula. Botanical Journal of the Linnean Society, 110, 137-156.

Lawes, M.J., Eeley, H.A.C., Shackleton, C.M., Geach, B.G.D. (2004) "Indigenous Forests and Woodlands in South Africa: Policy, People and Practice", pp. 139-165, University of Kwazulu-Natal Press, Scottsville, Pietermaritzburg.

Lebrun, J.P., Stork, A. (1991) Énumération des plantes à fleurs d'Afrique tropicale, IGénéralités et Annonaceae à Pandaceae.Conservatoire et Jardin botaniques de la ville, Genève.

Leme, FM., Scremin-Dias, E. (2014) Ecological interpretations of the leaf anatomy of amphibious species of Aeschynomene L. (Leguminosae Papilionoideae). Brazilian Journal of Biology, 74(1), 41-51.

Lemmens, R.H.M.J., Soerianegara, I., Wong, W.C. (1995) "Plant Resources of South-East Asia (PROSEA), No. 5(2). Timber Trees: Minor Commercial Timbers". Backhuys Publishers, Leiden, The Netherlands, 655p.

Egypt. J. Bot. 60, No.3 (2020) 
Masoko, P., Eloff, J.N. (2005) The diversity of antifungal compounds of six South African Terminalia species (Combretaceae) determined by bioautography. African Journal of Biotechnology, 4(12), 14251431.

Metcalfe, C.R., Chalk, L. (1950) "Anatomy of the Dicotyledons", Vol. 2, Clarendon Press, Oxford.

Milan, P., Hayashi, A.H., Appezzato-da-Glória, B. (2006) Comparative leaf morphology and anatomy of three Asteraceae species. Brazilian Archives of Biology and Technology, 49(1), 135-144.

Moshi, M.J., Mbwambo, Z.H. (2005) Some pharmacological properties of extracts of Terminalia sericea roots. Journal of Ethnopharmacology, 97, 43-47.

Muschler, R. (1912) "Combretaceae: A Manual Flora of Egypt". 2, pp. 673-674, R. Friedlaender \& Sohn, Berlin.

Naidu, A.C., Shah, G.L. (1981) Observation on the cotyledonary stomata and trichomes and their ontogeny in some genera of Lamiaceae. Phyton, 21, 137-152.

Narasimha Rao, G., Ramayya, N. (1984) Morphological and dermotype study of the leaves in six species of Terminalia L. Indian Journal of Botany, 7(1), 13-23.

Nawani, P., Kulshreshtha, K. (1982) Cuticular and epidermal studies in some species of Terminalia $\mathrm{L}$. Geophytology, 12(2), 273-278.

Noraini, T., Cutler, D.F. (2009) Leaf anatomical and micromorphological characters of some Malaysian parashorea (Dipterocarpaceae). Journal of Tropical Forest Science, 21, 156-167.

Ohri, D. (1996) Genome size and polyploidy variation in the tropical hardwood genus Terminalia (Combretaceae). Plant Systematics and Evolution, 200(3-4), 225-232.

Okeke, C.U., Iroka, C.F., Izundu, A.I., Okereke, N.C., Onwuasoeze, C.I. (2015) Comparative systematic leaf and petiole anatomical studies on the genus Stachytarpheta found in Awka. Nigerian Journal of Medicinal Plant Studies, 3, 82-88.

Paliwal, G.S., Malasi, C.B., Rajput, K.U. (1980) Multiplicity of stomatal types in Calotropis procera
R. Br. Proceedings of the Indian National Science Academy. Part B: Biol. Sci. 46, pp. 667-672.

Pedley, L. (1990) Combretaceae. In: "Flora of Australia", Vol. 18, pp. 255-293, Australian Government Publishing Service, Canberra.

Ramassamy, V., Kannabiran, B. (1994) Foliar epidermis and stomatal ontogeny in Terminalia. Indian Bot. Contactor, 10,107-111.

Rathinamoorthy, R., Thilagavathi, G. (2014) Terminalia chebula-Review of pharmacological and biochemical studies. International Journal of PharmTech Research, 6, 97-116.

Rodríguez, H.G., Maiti, R., Kumari, A. (2016) Research advances on leaf and wood anatomy of woody species of a Tamaulipan thorn scrub forest and its significance in taxonomy and drought resistance. Forest Research, 5(3), 1-9.

Satardekar, K.V., Deodhar, M.A. (2010) Anti-ageing ability of Terminalia species with special reference to hyaluronidase, elastase inhibition and collagen synthesis in vitro. International Journal of Pharmacognosy and Phytochemical Research, 2, 30-34.

Schmidt, E., Lotter, M., McCleland, W. (2002) "Trees and Shrubs of Mpumalanga and Kruger National Park". Jacana Media, Johannesburg, South Africa, 702p.

Seema, J., Meeta, B., Meenaksh, B., Manjushree, M. (2015) Comparative study of young and mature leaves of Terminalia catappa for evaluation of Physico-chemical, Pharmacognostical and Phytochemical analysis. Journal of Life Sciences, Special Issue, A4, 12-20.

Sharma, A.D., Mukundan, U. (2014) Pharmacognostic evaluation and metal analysis of Terminalia catappa Linn. leaves. Journal of Pharmacognosy and Phytochemistry, 2, 1-6.

Sickenberger, E. (1901) Contribution ā la Flora d'Egypte, Mémoire Institut Égyptien, 4(2), 167-332.

Smith, N.P., Scott, A.M., Henderson, A., Stevenson, D.W.M., Scott, V.H. (2004) "Flowering Plants of the Tropics". Princeton University Press, Princeton, New Jersey, 594p.

Egypt. J. Bot. 60 , No. 3 (2020) 
Solereder, H. (1908) "Systematic Anatomy of the Dicotyledons", Vol. 1, pp. 343-350 and Vol. 2, pp. 918-919. Clarendon Press, Oxford.

Srivastava, R.D., Dwivedi S., Sreenivasan K.K., Chandrashekhar, C.N. (1992) Cardiovascular effects of Terminalia species of plants. Indian Drugs, 29, 144-149.

Stace, C.A. (1965) The significance of the leaf epidermis in the taxonomy of the Combretaceae I: a general review of tribal, generic and specific characters. Botanical Journal of the Linnean Society, 59, 229252.

Stace, C.A. (2002) Proposal to conserve Terminalia nom. cons. (Combretaceae) against an additional name Bucida. Taxon, 51, 193- 194.

Steenkamp, V., Mathivhaa, E., Gouwsb, M.C., van Rensburga, C.E.J. (2004) Studies on antibacterial, antioxidant and fibroblast growth stimulation of wound healing remedies from South Africa. Journal of Ethnopharmacology, 95, 353-357.
Tilney, P. (2002) A contribution to the leaf and young stem anatomy of the Combretaceae. Botanical Journal of the Linnean Society, 138, 163-196.

Van Cotthem, W.R.J. (1970) A classification of stomatal types. Botanical. Journal of the Linnean Society, 63, 235-246.

Verhoeven, R.L. (1969) 'n Taksonomies- morfologiese ondersoek van die familie Combretaceae in SuidAfrika. M.Sc. Thesis, University of Pretoria, Pretoria.

Verhoeven, R.L., Van der Schijff, H.P. (1973)A key to the South African Combretaceae based on anatomical characteristics of leaf. Phytomorphology, 23, 65-74.

Verhoeven, R.L., Van der Schijff, H.P. (1974) Anatomical aspects of Combretaceae in South Africa. Phytomorphology, 24,158-164.

Wickens, G.E. (1973) Combretaceae. In: "Flora of Tropical East Africa", Polhill, R.M. (Ed.). Crown Agents for Oversea Governments and Administrations, London, United Kingdom. 99p.

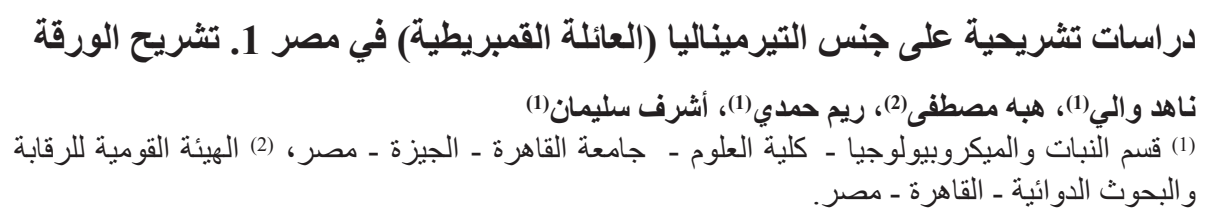

وجد أن جنس نبات التير ميناليا TERMINALIA ممثل في مصر بتسعة أنو اع. تم تحديد مو اقع الأنو اع المختلفة

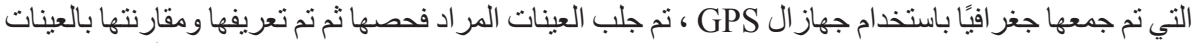

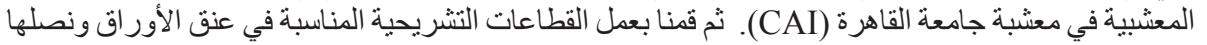

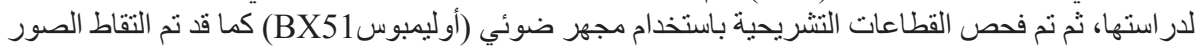

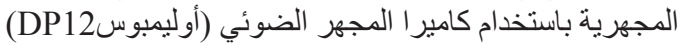

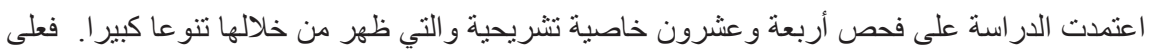

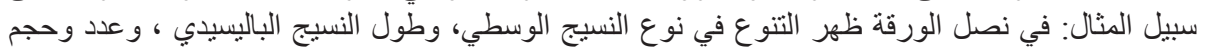

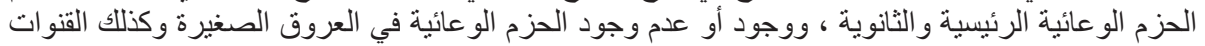

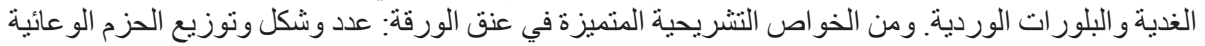

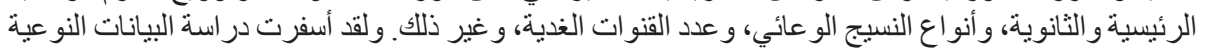

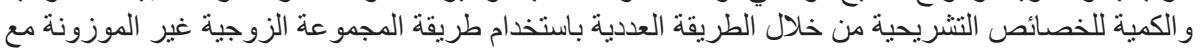

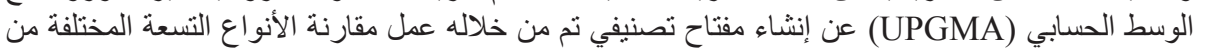
جنس التير ميناليا في مصر.

اقترحت هذه الدراسة أنه من المكن بل ويجب استخدام السمات التشريحية لعنق الورقة ونصلها لنبات التيرميناليا كمادة فعالة للمقارنة والتمييز بين الأنو التمن اعن المختلفة. 